Article

\title{
Do Corporate Social Responsibility and Corporate Governance Influence Intellectual Capital Efficiency?
}

\author{
Francesco Gangi ${ }^{1, *}$, Dario Salerno ${ }^{2}$, Antonio Meles ${ }^{1}$ and Lucia Michela Daniele ${ }^{1}$ (1) \\ 1 Department of Economics, Università degli Studi della Campania “Luigi Vanvitelli”, 81043 Capua, Italy; \\ antonio.meles@unicampania.it (A.M.); luciamichela.daniele@unicampania.it (L.M.D.) \\ 2 Department of Economics, University of Rome “Tor Vergata”, 00100 Rome, Italy; dario.salerno@uniroma2.it \\ * Correspondence: francesco.gangi@unicampania.it; Tel.: +39-0823274018
}

Received: 22 February 2019; Accepted: 26 March 2019; Published: 29 March 2019

\begin{abstract}
Using a large sample of public firms in 51 countries during the period from 2010 to 2015 and a two-stage least squares (2SLS) regression with an instrumental variable (IV), this study investigates how corporate social responsibility (CSR) and corporate governance (CG) mechanisms interact to influence a firm's intellectual capital (IC) efficiency. The empirical results reveal that CSR engagement and CG structures influence the firm efficiency in managing IC. This study contributes to managerial practice by demonstrating the causal effect of CSR on value-added intellectual capital (VAIC) measures and the positive impact of CG on both CSR engagement and the efficiency with which firms manage their IC. Furthermore, the current study provides an additional understanding of the relationship among CSR engagement, CG practices, and the determining factors of IC efficiency within a comprehensive framework.
\end{abstract}

Keywords: corporate social responsibility; corporate governance; intellectual capital; VAIC

\section{Introduction}

Corporate social responsibility (CSR) has become a mainstream topic in discussions of ethical and social issues regarding corporate decision-making and managerial behavior. Internal and external stakeholders continuously encourage companies to dedicate more resources to CSR initiatives. Particularly relevant among these are actions aimed at adopting progressive human resource management programs, protecting the environment, and being involved in community well-being initiatives. In parallel with the growing interest in CSR, large U.S. and European firms spend millions of dollars on sustainability consulting (e.g., in 2016, \$344 million and \$292 million, respectively, [1]). In addition, approximately $89 \%$ of Fortune Global 250 companies and $74 \%$ of the largest 100 companies by revenue publish detailed CSR reports [2]. CSR is equally important for investors because they acknowledge that it generates some type of competitive advantage and financial benefits. According to a survey by the SIF (Socially Investment Forum) Foundation in the U.S., institutional investors manage $\$ 2.56$ trillion in CSR assets. Similarly, in Europe, institutional investors manage approximately $90 \%$ of socially responsible assets, which amounted to $€ 22.892$ trillion in 2015 [3].

Considering the figures above, it is no surprise that a number of studies have recently devoted considerable attention to investigating whether CSR engagement is advantageous or detrimental to firms' wealth (e.g., References [4,5]). Whereas various studies (e.g., Reference [6]) note that CSR activities may help firms boost their performance by providing better access to appreciable resources and by encouraging employee commitment and customer loyalty, other authors (e.g., Reference [7]) have concluded that CSR initiatives may cause a waste of resources for firms and their shareholders. The existing literature has also shed some light on the reasons for these mixed findings, such as the difficulties in isolating CSR effects and the consequential persistence of statistical limits (e.g., 
Reference [8]). Margolis and Walsh [9] argue that various studies suffer from several imperfections such as measurement problems related to CSR engagement, omitted variable concerns, and a lack of methodological accuracy. Consistent with this view, more recent studies (e.g., Reference [10]) have found that analyzing the impact of CSR activities on corporate financial performance (CFP) without considering the influence of firm-specific characteristics, such as corporate governance (CG) mechanisms on both CSR engagement and CFP and not accounting for reverse causality problems, can lead to misleading conclusions.

From a theoretical and practical perspective, another shortcoming in the literature is that the previous studies have mainly investigated the relationship between CSR, CG, and traditional CFP indicators (e.g., Reference [11]), whereas only a few empirical works have examined the relevance of CSR and CG for the development of intellectual capital (IC), which is widely recognized as a major asset of modern business models due to its key role in achieving competitiveness (e.g., References [12-15]).

With regard to the relationship between CSR and IC, researchers have specifically shown a prevalent interest in the accounting implications of both CSR and IC reporting (e.g., References [16-23]). Accordingly, the prior studies adopt content analysis as the main instrument of investigation and fail to consider the managerial implications related to the impact of CSR on IC development. Thus, it is not surprising that Dumay $[24,25]$ solicited authors to abandon reporting disclosure to understand how an organization takes into consideration the ethical, social, and environmental impacts of CSR on IC. The managerial approach to the nexus between CSR engagement and IC dimensions is a topic that should characterize what Dumay [24] (p. 167) defines as the "third stage of IC research".

Moreover, the prior studies have mainly analyzed CSR's and CG's relationships with IC development separately. This approach has been employed in two bodies of research that fail to consider the connections between CSR and CG as pillars of a trustworthy organization. The benefits for stakeholders, reliable relationships among people within and outside the company, an improved reputation, and the sharing of knowledge are aspects that are common to CSR engagement, CG mechanisms, and IC development that the prior literature has not sufficiently investigated through a unique framework of study.

Further, the previous empirical studies on the links between CSR and IC and between CG and IC show several methodological limitations. An overlooked aspect is that most of the research is geographically limited, and the empirical tests are performed on small samples with reference to a specific industry (e.g., References [15,26-33]). Moreover, some studies adopt univariate tests (e.g., Reference [29]) or adopt cross-sectional data (e.g., Reference [28]) that impede causality examination, whereas other analyses minimize the reverse causality effects (e.g., Reference [15]). In the prior models, the explicative variables are mainly self-constructed through surveys administered to representatives of the sampled companies (e.g., References $[15,28]$ ), thus generating somewhat subjective analyses.

Based on this background, the current study has the objective to fill the aforementioned gaps by examining how CSR as a whole and CG best practices can positively impact IC development. Therefore, our analysis aims to contribute to the existing literature in several ways.

Firstly, the confirmation of CSR as being antecedent of valuable resource, such as IC, would shed light on the equivocal and open question of the business effects of CSR engagement. In particular, due to the link between IC and firm competitiveness, a positive relationship between CSR engagement and IC would corroborate the theoretical conception of CSR as a co-specialized asset that increases the value of a strategic and intangible asset such as IC. Therefore, the current study aims to contribute to advancing the knowledge on the debated relationship between CSR and CFP.

Secondly, since CSR is a multidimensional construct, by assuming that CG is a pillar of CSR [34-36], the current study intends to verify whether the positive effects of a co-specialized asset [37] can be attributed to a single dimension of CSR, such as CG best practices. This approach enables the disentanglement of the effects of CG from the general impact of CSR engagement on IC dimensions. In this vein, as far as can be ascertained, our paper aims to provide the first evidence on the double link between CSR as a whole and IC dimensions and between the latter and effective CG mechanisms. 
Thirdly, by capturing the points of convergence stemming from a stakeholder approach to CSR engagement, CG mechanisms, and IC development, the current paper aims to respond to Dumay's [25] call for a shift of the research focus on IC development from an accounting to a management perspective. Indeed, for Dumay, the CSR engagement represents an important opportunity to expand the research agenda on the management of IC, instead of concentrating on synergies among IC reporting and CSR disclosure.

Furthermore, relative to prior literature, the current study aims to advance the methodological design for empirical evidence on the link between CSR, CG, and IC. In particular, we collected longitudinal panel data on a large sample of international public firms for which we have information for the 2010-2015 period. Additionally, our estimates employ the instrumental variable (IV) approach for the treatment of reverse causality. Finally, the econometric models of this paper adopt data on CSR engagement drawing from the Asset 4 dataset provided by Reuters. As noted in the previous studies (e.g., Reference [38]), Asset4 generates transparent, auditable, and comparable information for the evaluation of corporate social performance.

With the awareness that measuring IC performance is still an open question [18], we estimate the financial contribution of IC performance through value-added intellectual capital (VAIC) by Pulic [39], a model that has been widely used as the primary measure of IC (e.g., Reference [31,40-42]). Consistent with Iazzolino and Laise [43] and relative to the indicators that measure value creation from shareholders' perspective, VAIC measures value creation from the stakeholder perspective and clearly accounts for IC.

Therefore, to achieve the objectives of the current study, the remainder of this paper is organized as follows. Section 2 presents the conceptual framework and the hypotheses. Section 3 explains the design of the empirical study. Section 4 summarizes the results. Section 5 provides the theoretical conclusions and managerial implications Finally, Section 6 includes the study's limitations and suggestions for a future research agenda.

\section{Literature Review and Hypotheses Development}

Figure 1 shows a synthesis of the conceptual framework of the current study. In particular, the purpose of our work is to check if and how corporate social responsibility (CSR) can be considered a driver of intellectual capital development (IC) that, in turn, contributes to CFP. The aim is to investigate two topics addressed by the previous literature, mainly in a separate manner. On the one hand, we refer to the debated topic of CSR's impact on financial performance. The findings of the meta-analyses range from small [44] to medium [45] to significantly positive links between CSR and financial performance [46]. On the other hand, we refer to the less-investigated theme of the impact of CSR on IC from a management perspective [15,27,28,47-49]. To integrate these two lines of investigation, the present study assumes the concept of CSR as a "cospecialized asset" [37] (p. 1491) with the capacity to increase the value of other assets, which, in turn, contribute to the firm performance. In this regard, we focus on IC as a critical resource to the competitive success of the firm $[14,17,28,31,50,51]$. Therefore, we aim to provide new insights on both the link between corporate social performance and CFP and between the former and IC development. The latter, in fact, represents a useful mediator construct [14] that may help to explain the contribution of CSR to the generation of sustainable value and competitive advantage.

Conceptually, CSR and IC have a common feature. In fact, they are both multidimensional concepts with important implications on theoretical and practical levels. In particular, social responsibility is essentially of a multidimensional nature [52], encompassing the three main pillars of environmental sustainability, community relations, and best CG practices [35]. At the same time, with reference to IC, there is a broad consensus that it consists of different dimensions such as human capital, structural capital, and social/relational capital [12,14,51,53].

The current study mainly addresses policies that pertain to the internal dimension of CSR [54-56]. The latter can contribute to the development of IC not only through the management 
of human resources $[15,57]$ but also through the ethics, transparency. and effectiveness of CG mechanisms, $[29,31,32,50]$. Indeed, prior literature has found that CG has a significant impact on internal CSR issues, such as employee conditions and the ethical aspects related to managerial and employee behavior [58,59]. From a broader perspective than that of the agency model $[60,61], C G$ and IC have in common the value-creation process for stakeholders and a socially responsible CG has the fiduciary responsibility of developing IC [50]. Therefore, in our analysis, we first consider the link between CSR as a whole and the development of IC. Subsequently, we adopt an approach that deconstructs CSR to verify if and how the CG dimension of CSR may have an impact on IC.

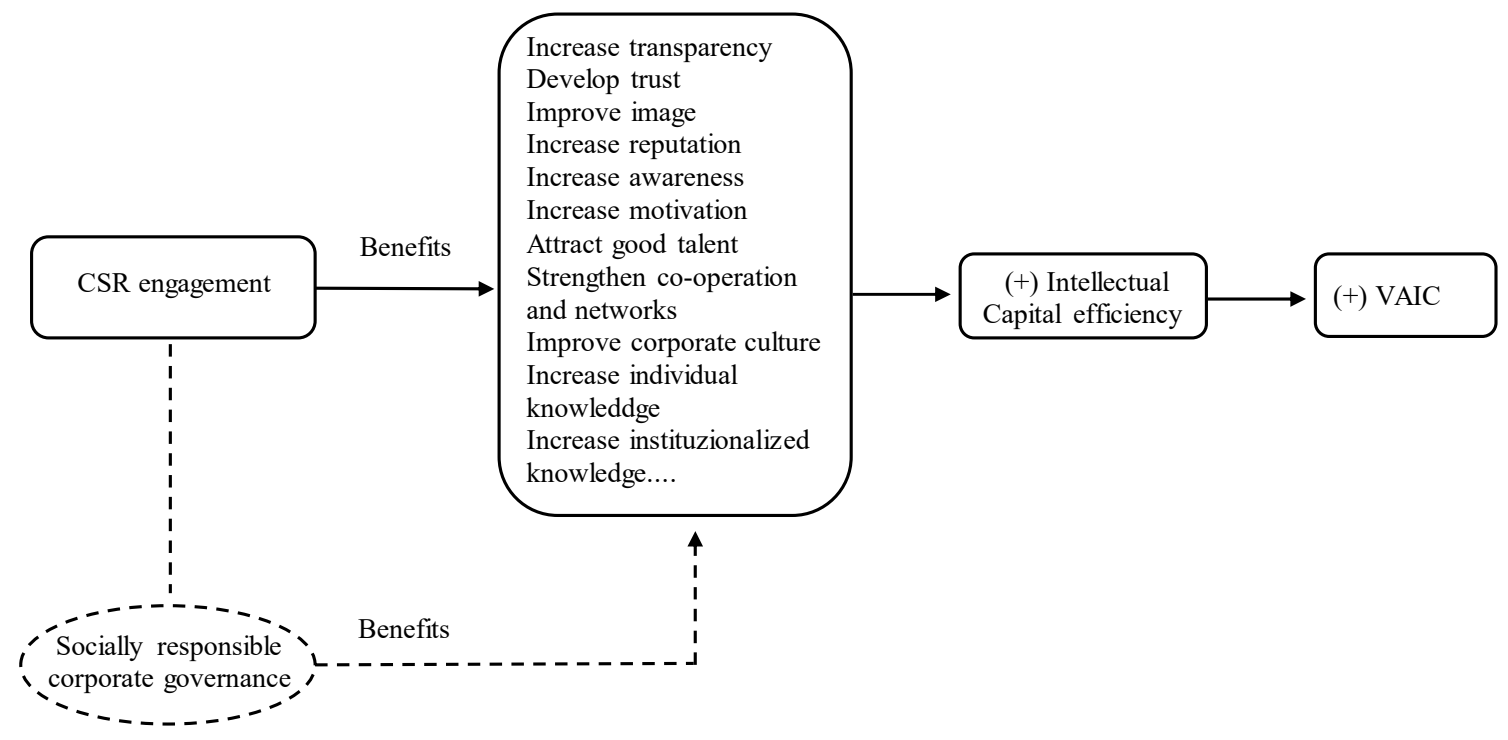

Figure 1. The conceptual framework; source: author's own elaboration.

Finally, for both the steps of our study, we need to search for a synthetic quantitative measure of IC as the mediating construct among CSR, CG, and organizational performance. In fact, the difficulty of measuring IC due to the multidimensional and intangible nature of the IC concept is widely acknowledged by the prior studies $[14,31,62]$. This topical point was addressed by an earlier literature through the use of different indicators ranging from financial market-based to accounting-based data to evaluate the contribution of IC in terms of economic value [18].

Therefore, given the purpose of the current study, this section focuses on three aspects. First, we concentrate on IC as a valuable resource in obtaining a competitive advantage. Subsequently, we deepen two relationships: first, the link between CSR engagement and IC, and second, the impact of CG on IC development.

\subsection{IC as a Critical Resource for Firm Performance}

During the end of the last century and the beginning of the new millennium, the emergence of the knowledge-based economy determined knowledge as the major asset of modern business $[17,28]$ and the management of knowledge as essential for the success of modern firms [63]. Knowledge is not only held by individuals but also generated through interactions among people and through the social exchanges between the organization and its external environment. In fact, whereas individuals are holders of tacit knowledge, the organization and interactions among people play a central role in making explicit, justifying, and integrating individual knowledge [64,65]). This continuous dialogue between tacit and explicit knowledge favors the creation of new knowledge [64]. Furthermore, since an organization does not own the individuals working in it, socialization and interactions among people are essential processes for converting tacit knowledge into organizational knowledge to the greatest extent possible. From this combination emerges the possibility of accumulating knowledge resources that are firm-specific and, hence, rare and less imitable, leading to a sustainable competitive advantage 
in the long-term [66]. In this respect, "intellectual capital refers to the sum of all intangible knowledge resources - the sum of all individual and organizational knowledge and capabilities-a firm can utilize for competitive advantage." [28] (p. 89). In the same vein, the prior literature defines IC as "the sum of all knowledge an organization is able to leverage in the process of conducting business to gain competitive advantage" [51] (p. 337).

From the above definitions, we can grasp the multidimensional nature of the IC construct that encompasses human capital (HC) and structural capital (SC). Additionally, prior literature [13] extends the IC concept to the relational capital (RC).

The first category (HC) pertains to individual employees' knowledge, skills and abilities. These knowledge resources are those adopted by employees to accomplish their tasks and achieve the goals of the organization to which they belong [28].

The second category (SC) represents the outcome of the development of institutionalized knowledge through routines and behaviors rooted in the corporate culture and procedures $[15,67]$. Consistent with prior literature [12,14,53], SC is the capital actually owned by an organization. Intentional and effective knowledge management helps to convert tacit and noncodified knowledge into organizational knowledge and capabilities, both operational and dynamic [68], which are the ultimate sources of competitive advantage. Therefore, SC encompasses the knowledge resources owned by a business, including the organizational procedures, patents and manuals, management philosophy, corporate culture, and corporate identity [28].

Finally, the third category of IC has received different definitions by the prior literature. In particular, some authors refer to relational capital (e.g., References [18-20,27]), while other adopt the concept of social capital [14,28,51]. Indeed, consistent with Youndt and Snell [14] (p. 338), the two concepts are convergent as social capital $[69,70]$ in organizational and sociological theories is "virtually identical" to what Bontis [53] called relational capital. In particular, the latter is an extended concept of customer capital [12] that pertains to the value of all relationships. Bueno et al. [71] stated that $\mathrm{RC}$ is a new concept derived from the multiagent relationships of the current economy. In line with Adler and Kwon [70] and with Nahapiet and Ghoshal [72], Youndt and Snell [14] argue that RC is an intermediary form of IC that does not reside at the individual or organizational levels. RC consists of knowledge resources that are embedded within, available through, and derived from networks and relationships. RC is a dimension linked to other assets such as brand image and corporate reputation. With regard to the latter, Barney [73] considers reputation to be a complex social capability which is characterized by a high rate of intangibility and tacit knowledge [74].

In sum, all the aforementioned categories of IC drive the accruing of knowledge in different ways, i.e., HC through individuals, SC through processes and systems, and RC through relationships and networks within and outside the organization. Together, the concepts of $\mathrm{HC}, \mathrm{SC}$, and RC can provide a holistic view of the resources that are critical for business success.

However, as argued by Youndt and Snell [14], IC belongs to those variables that are most theoretically interesting but that are least measurable in terms of economic value due the intrinsic nature as intangible assets based on knowledge. Thus, the main feature of IC as a variable of great relevance for competitive advantage is also a source of great complexity when a study aims to quantify its financial contribution. Consistent with Pedrini's literature review [18], in the past, several instruments have been adopted to measure and monitor IC. From an accounting-based perspective, a widely used quantitative measure of IC is VAIC, the value-added intellectual capital model (e.g., References $[27,31,39,75-77]$. In particular, this model was implemented to measure IC efficiency and, thus, the contribution to firm financial performance. Therefore, the greater the VAIC coefficient, the higher the value-added of the overall critical knowledge resources. We deepen the VAIC model in the methodology section of the current study. 


\subsection{The Link between CSR and IC}

In the modern economy, wealth creation no longer depends on physical assets but rather on intangible assets, and IC is considered to be the lever for generating and maintaining competitive advantage and sustainable corporate performance [42,71]. In this scenario, CSR may play a critical role from the perspective of IC management. With an emphasis on sustainable development López-Gamero et al. [47] argue that sustainability should be extended to all the pillars of IC.

Indeed, in the broad debate on CSR benefits, the central question is well-known: "Does it pay to be good?" [78] (p. 1304). Prior research has widely discussed whether CSR actions may lead to positive changes in firm performance (e.g., References [9,45,78-81]). However, very few studies have analyzed and empirically tested the relevance of CSR for IC development (e.g., References [15,27,28,47,48]). Most of the prior research has deepened the relationship between CSR and IC, mainly from an accounting point of view, by focusing on the convergence of CSR reporting and IC reporting (e.g., References [16-23,25]). In his manifesto for transformational IC research, Dumay [26] advises researchers to face new challenges in IC studies by reconsidering the reporting approach to IC, thus soliciting an increasing interest in managing IC and in IC praxis. The current study answers Dumay's call. In particular, beginning with the conceptual construct of cospecialized assets proposed by McWilliams and Siegel [37], CSR can be considered an asset that can make IC a more valuable resource than it would be if a company were less engaged in CSR activities. This association contributes to the explanation of why a CSR-based strategy can generate a better performance due to intangible resources that prevent competitors from imitating a company strategy.

While the CSR concept continues to change its connotation, a clear tendency is the enlargement of the CSR framework by including sustainable development and ecological footprints of business [82]. Accordingly, authors (e.g., Reference [83]) refers to the concept of corporate social and environmental responsibility (CSREM) as an antecedent of corporate financial performance. Cheng $[84,85]$ argued that the enhancement of environmental culture among employees contributes to a sustained competitive advantage due to the positive influence of green intellectual capital and innovation on firms' performances. Companies are paying more attention to environmental sustainability as a complement to differentiation objectives [86] or are making serious efforts in integrating the environmental commitment into the organizational knowledge and identity [87]. From this perspective, Boiral [88] states that the tacit knowledge embedded in HC represents one of the main sources of environmental innovation. Employees called to integrate environmental issues into their operations, actively participating in the definition and implementation of environmental policies and, thus, accelerating the process of the transformation of tacit in explicit knowledge. In a similar vein, Nikolaou [83] asserts that environmental investments assist firms in building a competitive advantage through tacit and explicit knowledge creation that fosters environmental innovative products and management procedure. This is consistent with Chen et al. [89] that found innovation capital as a significant source of business performance. In other words, the link between corporate social and environmental responsibility and IC contributes to the justification of the uniqueness of firm-specific resources of a sustainable competitive advantage.

Guthrie et al. [17] argue that, in a knowledge-economy era, organizations must manage IC effectively and leverage it for the benefit of their stakeholders. At the same time, CSR is concerned with treating firm's stakeholders in an ethical and responsible manner [90]. Hence, even if CSR and IC are two distinct phenomena, CSR actions can have an impact on IC along its different dimensions.

First, the HC dimension encompasses employees' knowledge, skills, and attitudes. At the same time, the interest in people employed in an organization is one of the pillars of modern CSR, which integrates a business's social and economic responsibilities [57,91]. In particular, CSR activities involve employees' welfare and business ethics in several ways that can improve human resource management and a firm's capability to attract and retain better qualified employees [92]. Thus, internal CSR policies that encompass relationships with employees can improve the motivation, efficiency, and performance of the individuals involved in the organization [8]. In a similar vein, Brekke and 
Nyborg [93] recognized that the provision of CSR allows companies to develop human resources capabilities to the extent that CSR can be understood as a labor market screening approach that allows firms to attract highly motivated and productive employees. Consistent with Branco-Castelo and Rodriguez-Lima [94], CSR activities may develop HC by improving existing employees' loyalty and commitment to the company. This aspect has a strategic value as individual employees hold an uncoded form of knowledge that is tacit in nature and less convertible in writing because this tacit form of knowledge is rooted in personal experience and values $[64,95,96]$. Even if the development of information and communication technologies facilitated the storage of an explicit knowledge (codified), the tacit knowledge still resides in people's minds. Therefore, if the tacit knowledge of an organization can exist only in the form of its employees [97], then the sharing and use of this specific knowledge dimension will depend upon individual decisions and trust relationships [63]. These concepts are meaningful for understanding the impact of CSR engagement on the HC dimension. In fact, CSR may enhance knowledge socialization [64] based on the creation of trustworthy relationships. Trust is itself a resource that mitigates the perceived risks of sharing tacit knowledge among people [98]. Consistent with Mårtensson [99], employees may be reluctant to share their expertise because they are competitive by nature and inclined to protect rather than share their knowledge. Aiding in the management of tacit knowledge embodied in people [100], CSR may be a mode that makes the socialization of knowledge between individuals and groups more fluid [101] relative to companies that are less adept at CSR [63,102]. Furthermore, in terms of value creation, as human resources, in general, represent a significant cost for balance sheets, being socially responsible creates advantages for companies in terms of enhanced recruitment, retention, and employee productivity. These goals may more than offset the extra costs of CSR engagement [37,103]. Brammer et al. [54] argued that social performance has a positive impact on the attraction, retention, and motivation of employees because they are likely to identify with positive organizational values.

The HC dimension has connections with the SC dimension. From this perspective, IC means a more solid organizational culture, an increased attitude toward the innovation of products and processes, in addition to a more productive behavior among employees [15]. CSR is transversal to all these resources. In particular, CSR can be the foundation for a sustainable corporate culture that provides a group identity for the people employed by an organization. CSR initiatives may enhance employees' commitment and their identification with the company [55]. The adherence to ethical values and conduct can form an organizational culture by promoting trustworthy behaviors. $\mathrm{Su}$ [28] argued that "such a culture is itself an important component of organizational capital, while it also constitutes a positive environment for generating further organizational capital." Trust in an organization stimulates creativity among people and teams as each person perceives the existence of lower barriers to the free expression of ideas and opinions. Through a climate of trust and shared values, internal CSR may positively contribute to the organizational knowledge that is embedded in human resources and managerial skills [54]. In such a climate, employees feel that they will be rewarded for their contribution to a trustworthy business [104]. This means the opportunity to accrue additional SC through business models that reinforce ethical conduct and establish a trustworthy culture $[27,28]$.

Furthermore, CSR engagement also involves RC. The latter is the set of resources embedded within, available through, and derived from networks of relationships. A broader conceptual construct includes the capacity of employees to create, transfer, and leverage knowledge with one another, which also has an impact on customer relationships, external partnerships, and other associations [14]. This is consistent with a business case approach to CSR that results in the acquisition of new clients and the improvement of corporate image and reputation [27]. McWilliams and Siegel [37] argue that the clearest example of CSR's functioning as a cospecialized asset is its positive impact on firm reputation. The latter depends on the interactions among people within and outside the organization and among organizations. According to prior literature [8], business reputation can be considered a key channel for the impact of CSR policies on firm competitiveness. The citizenship performance of 
a corporation fortifies its relationships with external stakeholders and improves the organization's image $[44,105,106]$. Reputation is a fundamental driver of RC. Firms that engage in CSR obtain a positive impact on reputation [52] and may accrue RC [107], which in turn generates a set of business benefits such as lower labor costs [37], premium prices, and customer loyalty [108] [109,110], thus increasing the attention of investors and lowering funding costs [111]. Lin et al. [48] found that CSR has a positive impact on financial performance due to a positive relationship with RC.

Finally, in the literature, there is some agreement that CSR involves voluntary attention to the ethical implications of business [112,113]. Therefore, consistent with Su [28], we can assume that the endorsement of ethical values allows a business to build a trustworthy environment that promotes reciprocity and trust among stakeholders, thus increasing corporate goodwill and value.

Therefore, in line with the above arguments, we hypothesize the following:

Hypothesis 1. There is a significant and positive relationship between CSR engagement and IC.

\subsection{The Link between CG as a CSR Pillar and IC}

From a stakeholder perspective [114], CSR can be considered a multidimensional and multifaceted construct [115] that includes a CG dimension [8,35]. Consistent with this assumption, to advance the state of knowledge on CSR effects on IC, it is useful to disentangle the link between CSR and firm performance by considering how the CG dimension might play a role in IC development. This is a topical point based on the wide debate around the relationship between CG and CSR $[7,34,36,116]$.

In a general sense, CG is defined as "the system by which companies are directed and controlled" [117] (p. 8). According to theorists of the agency model $[60,116,118]$, the aim of CG is to avoid conflicts of interest between managers and owners. Consistent with this narrow vision, CG should limit CSR, as the sole social responsibility of companies is to make as much profit as possible and as CSR is considered a specific case of a wider structural agency problem between managers and shareholders [37]. First, CSR is compared to a non-authorized form of taxation for shareholders [60]. Second, consistent with the overinvestment hypothesis [119], managers would pursue their own interests in terms of image and good reputation while they engage in CSR activities, thereby creating agency costs [118]. Third, a stakeholder approach to CG should make managers less accountable for their actions [108]. Consistent with a narrow vision, CG is expected to lower CSR engagement and, hence, would not contribute the enhancement of IC dimensions.

However, over the years, authors have demonstrated a growing interest in an opposing conception about the aim of CG and its link with CSR. In particular, a socially responsible CG would be necessary to guarantee responsible behavior toward all business's stakeholders [34,35,50,120-123]. Indeed, this conception has deep roots in the seminal work of Berle and Means [124] (p. 356) that highlighted how "neither the claims of ownership nor those of control can stand against the paramount interests of the community ... corporate leaders should set forth a program comprising fair wages, security to employees, reasonable service to their public, and stabilization of business, all of which would divert a portion of the profits from the owners of passive property, and should the community generally accept such a scheme as a logical and human solution". Therefore, an opposing view relative to the agency model is a broader idea of CG as a pillar of CSR. Years later, Tricker [125] argued that CG involves interactions not only with owners but also with others interested in the affairs of the company.

The prior studies empirically demonstrate how CG can be considered the missing link between CSR engagement and firm performance $[36,126]$. Overcoming the agency theory, CG serves not only the interests of the ownership but also those of a wider range of constituents that includes employees, customers, and community members [127]. In this sense, a socially responsible approach to CG can contribute to solving rather than emphasizing conflicting interests among different groups, realizing the win-win effect of CSR practices [128]. In line with these arguments, Jamali et al. [34] argue that companies with effective CG create and maintain better trust relationships with customers, the community, and other stakeholders such as employees who are important to the company's 
sustainability by providing it with the necessary resources for its survival, competitiveness, and success. Birindelli et al. [129], analyzing the relationship between board composition and environmental, social, and corporate governance (ESG) performance in the banking industry, found that organizations equipped with a CSR committee gained greater ESG performance, representing the committee as a strategic tool for maximizing sustainability opportunities and facilitating dialogue between CG and stakeholders. Thus, if managers are accountable toward stockholders, whose wealth is at stake, then this does not mean that they are not responsible toward employees and other stakeholders [36]. In a similar sense, Kennan and Angestan [50] (p. 270) spoke about the impact of "ambivalent" CG decision making on simultaneously competing dimensions. Harjoto and Jo [10] highlight that CSR engagement in the CG dimension reduces the conflict of interest between managers and non-investing stakeholders, thereby improving operating performance and firm value. If much of the organizational knowledge resides within HC paradigms and, simultaneously, firm performance tends to emanate from such knowledge, then governing bodies are needed to create the best conditions for leveraging the HC stock to attain and sustain a competitive advantage in the market [32]. In a similar vein, Hancock [120] depicts CG as one of the main pillars of CSR along with human capital.

In an operating sense, another point of contact between CG, CSR, and IC can be found in the role of the chief executive officer (CEO). In particular, the CEO is an interpreter and a recipient of CSR activities. The CEO's personal values, culture, and experience contribute to the definition of the sensitivity for and guidelines of CSR engagement, including the fixation of parameters and the level of CEO compensation as the objects of a transparent CG mechanism. This should feed a climate of trust within the organization and outside it. Waldman et al. [130] found a positive correlation between the intellectual stimulation dimension of CEO leadership and the propensity of a firm to be socially responsible. Ying et al. [49] highlighted that the support to IC for a superior competitive advantage was largely driven by top management skills and engagement in fostering IC culture inside organizations. Altuner et al. [29] proposed a triangulation among CG, IC, and CSR with the aim to demonstrate the positive linkages among these concepts and firm facets. Further, CG mechanisms are strictly concerned with honesty and transparency [34]. The latter are values that can facilitate the development of trust as a complementary governance mechanism of social exchanges [30]. In this sense, reliable CG should prevent opportunistic behaviors among a business and its stakeholders, thus aiding the accruing of SC.

Therefore, the relationship between CG and IC can be viewed under different dimensions. Keenan and Aggestam [50] recognized that CG had a fiduciary responsibility for creating and leveraging IC embedded in the people, structures, and processes of a company. The authors argued that corporate governors must manage the challenge of considering human capital with the same diligence they devote to financial capital. In all systems of CG, attention to IC is important because this intangible asset transforms tangible and financial capitals into added value and wealth. Thus, the intensity of the link between CG and IC would influence the consideration that CG systems are themselves IC systems [50]. Accordingly, Ho and Williams [26] stated that the board of directors could be considered a part of a firm's human capital and that its composition could influence an organization's overall IC efficiency. Dittmar and Mahrt-Smith [131] argued that responsibility for the development of IC resided in firms' CG mechanisms. Consistent with this argument, Saifieddine et al. [132] highlighted a positive relationship between CG and IC and that effective CG was more likely to bring IC to an organization. They further contended that a poor CG mechanism could induce an inability to attract and retain IC within the organization. Thus, firms with effective CG mechanisms were likely to focus their efforts on activities that could add value to the organization through IC by designing a healthy and safe workplace, establishing training and education programs, hiring experts in the field, improving processes and systems, enhancing diversity and equal opportunity, and developing trustworthy relationships with all stakeholders. Consistent with the aforementioned assumptions, Wang [30] founds that IC was positively related to firm valuation and that CG had a moderating effect by influencing the positive relationship between IC and firm valuation. In a similar vein, by focusing on internal CG mechanisms to protect outside investors against expropriation by insiders, Appuhami 
and Bhuyan [31] found that firms might experience a significant association between IC efficiency and some board characteristics such as CEO duality and board composition.

Accordingly, socially responsible CG mechanisms are suspected to have an impact on all three components of IC. First, effective CG may contribute to the transparency within the organization, thus feeding a climate of trust that may strengthen the sharing of knowledge among employees that leads to the development of HC. Second, best CG practices may improve corporate culture, routines, codes of conduct, and procedures that are elements of SC. Third, effective CG contributes to corporate image and reputation that, in turn, increases the accruing of SC.

Therefore, in line with these arguments, we hypothesize the following:

Hypothesis 2. There is a positive relationship between effective CG mechanisms and IC.

\section{Data, Variables, and Empirical Strategy}

\subsection{Variable Measurement and Identification}

\subsubsection{VAIC Measure}

Following various studies (e.g., References [76,77]), this paper uses the VAIC as a proxy of the value added (VA) by a firm's human capital (HC), structural capital (SC), and capital employed (CE).

In line with this, the first step in measuring the VAIC is to calculate the VA, which is computed as the sum of operating profit (OP), employee costs (EC), depreciation expenses (DP), and amortization expenses (AE).

$$
\mathrm{VA}=\mathrm{OP}+\mathrm{EC}+\mathrm{DP}+\mathrm{AE}
$$

After that, the model estimates $\mathrm{HC}$ by summing all employee-related costs and $\mathrm{SC}$ as the difference between VA and HC (SC = VA $-\mathrm{HC})$.

The third step in calculating VAIC focuses on estimating HC efficiency (HCE), SC efficiency (SCE), and CE efficiency (CEE). HC efficiency is measured by dividing VA with HC (HCE = VA/HC). Otherwise, SC efficiency is calculated as the ratio between SC and VA (SCE = SC/VA). Finally, $\mathrm{CE}$ efficiency is the ratio between VA and invested capital, i.e., the difference between the total assets (TA) and the intangible assets (IA) (CEE $=$ VA $/(\mathrm{TA}-\mathrm{IA})$ ).

VAIC represents the sum of the abovementioned efficiencies (VAIC $=\mathrm{HCE}+\mathrm{SCE}+\mathrm{CEE}$ ), while the sum of HCE and SCE measures the efficiency of IC.

As highlighted by previous studies (e.g., Reference [133]), the motivation for estimating VAIC in this way is that companies with higher VAIC values are more likely to better use their IC, and, therefore, the value created will likely be improved.

Although VAIC has been widely employed in the empirical research as a measure of IC efficiency [134], it suffers from several drawbacks (for details see References [133,135]). In spite of this, in their study, Iazzolino and Laise [43] (p. 548) determined that VAIC "is a method that complements those existing and for this reason, it can be usefully included, as an innovative indicator of intellectual capital efficiency".

\subsubsection{CSR Measures}

We use a measure of CSR engagement (CSR_1) similar to that used by Gangi et al. [101] and obtained from ASSET4's ESG score. In particular, the ESG score is based on three pillars (environmental, governance, and social) about which ASSET4 provides 178 indicators that are divided into 10 categories: resource use, emissions, innovation, management, shareholders, CSR strategy, workforce, human rights, community, and product responsibility. Furthermore, as some governance variables are used in econometric analyses as independent variables and included in the calculation of a firm's ESG score, we account for the possibility that reverse causality issues may affect our results. Therefore, as a 
robustness check, we consider another measure of CSR without the CG indicators, such as the average of the social and environment scores proposed by Thomson Reuters' ASSET4 (CSR_2).

\subsubsection{Board Characteristics}

The role of board characteristics in performance improvement has been widely discussed in prior literature (e.g., Reference [50]). To identify a firm's board characteristics, we selected the following variables based on a review of the prior studies (e.g., References [136,137]).

First, the variable Board Size (B_Size) is measured as the natural logarithm of the number of board directors. Second, the variable Board Independence (B_ind) is calculated as the number of independent directors divided by the total number of board directors.

Third, and finally, the variable Board Gender (B_GD) is measured as the number of female directors divided by the total number of board directors.

\subsubsection{CEO Characteristics}

The ability to influence the decisions made by the board of directors also depends on the characteristics of the CEO [138]. In this study, we use two variables to capture CEO characteristics. First, we use CEO-chairman duality (CEO_power), which is a dummy variable set as equal to one when the CEO simultaneously chairs the board and to zero when the chairman of the board has been the CEO of the company. Second, we use CEO Compensation Link to Total Shareholder Return (CEO_comp), which is a dummy variable set as equal to one when managerial compensation is linked to total shareholder return and to zero otherwise.

\subsubsection{Control Variables}

Because company characteristics can affect both CSR engagement and a firm's IC efficiency, we control for several firm characteristics to mitigate concerns about omitted variables. TA is the natural logarithm of total assets. Age is the natural logarithm of a firm's age. Sales_growth is the firm's sales growth rate over the previous two years. Capital ratio is the book value of total equity divided by the total assets. Capex is the capital expenditures normalized by the total assets.

\subsection{Sample Construction and Descriptive Statistics}

To investigate the hypothesis that CSR activism and CG characteristics are valuable for improving firm IC development, we collect data on CSR from Thomson Reuters' ASSET4, which has been extensively used by previous studies (e.g., Reference $[139,140])$.

We begin by examining the full list of public companies supplied by Thomson Reuters. Then, we delete from the list companies for which we do not find ESG information for one or more fiscal years between 2010 and 2015. In addition, we do not consider companies operating in the financial industry because they cannot be directly compared to industrial and other service firms. This data collection yields a sample of 2480 firms from 51 countries over the period from 2010 to 2015 (for a total of 14,880 firm-year observations). Furthermore, we match the ASSET4 data with the Thomson Reuters "Datastream" to collect financial and CG data and with the Bureau Van Dijk Orbis to collect the data necessary to estimate the VAIC. In doing so, we restrict the final sample due to missing data on several governance variables, VAIC and certain firm-specific control variables. Despite such missing data, our econometric analyses maintain approximately 1800 firm-year observations. Table 1 reports the descriptive statistics of firm-specific characteristics (Panel A) and IC efficiency (Panel B) for firms with a high and low CSR, less and more independent boards, a low and high board gender diversity, a small and large board size, CEO compensation, and CEO separation. Overall, there are statistically significant differences among the firm-specific variables and IC efficiency between firms engaging in a high and low CSR and with different CG structures. This evidence makes it necessary to control for endogeneity when we analyze the impact of CSR and CG structures on VAIC. 
Table 1. The descriptive statistics and univariate test (to be continued).

\begin{tabular}{|c|c|c|c|c|c|c|c|c|}
\hline \multicolumn{4}{|c|}{ Firms Engaging in a Low CSR } & \multicolumn{3}{|c|}{ Firms Engaging in a High CSR } & \multicolumn{2}{|c|}{ Difference Tests } \\
\hline & \multirow{2}{*}{$\mathrm{N}$} & \multirow{2}{*}{ Mean } & \multirow{2}{*}{ Median } & \multirow{2}{*}{$\mathrm{N}$} & \multirow{2}{*}{ Mean } & \multirow{2}{*}{ Median } & T-stat & z-stat \\
\hline & & & & & & & ( $p$-value) & ( $p$-value) \\
\hline \multicolumn{9}{|c|}{ Panel A: firm characteristics } \\
\hline TA & 7437 & 21.85 & 21.89 & 7436 & 23.03 & 22.96 & 0 & 0 \\
\hline Age & 4591 & 3.16 & 3.18 & 5123 & 3.51 & 3.52 & 0 & 0 \\
\hline Growth & 744 & 0.21 & 0.04 & 744 & 0.03 & 0.02 & 0 & 0 \\
\hline Capital ratio & 7437 & 0.46 & 0.46 & 7436 & 0.41 & 0.4 & 0 & 0.0004 \\
\hline Capex & 7402 & -0.06 & -0.04 & 7425 & -0.06 & -0.05 & 0 & 0.8187 \\
\hline \multicolumn{9}{|c|}{ Panel B: IC efficiency } \\
\hline VAIC & 1342 & 5.25 & 2.97 & 1345 & 5.81 & 2.62 & 0.0509 & 0 \\
\hline \multicolumn{4}{|c|}{ Firms with a Less Independent Board } & Firms & More Ind & ent Board & Differe & ce Tests \\
\hline & $\mathrm{N}$ & Mean & Median & $\mathrm{N}$ & Mean & Median & T-stat & z-stat \\
\hline & & & & & (ק) & 19. & ( $p$-value) & ( $p$-value) \\
\hline TA & 7531 & 22.46 & 22.43 & 7342 & 22.41 & 22.37 & 0.0378 & 0.003 \\
\hline Age & 3653 & 3.34 & 3.34 & 6061 & 3.35 & 3.33 & 0.4491 & 0.4899 \\
\hline Growth & 7533 & 0.1 & 0.01 & 7347 & 0.14 & 0.04 & 0.3652 & 0.0159 \\
\hline Capital ratio & 7531 & 0.44 & 0.43 & 7342 & 0.43 & 0.43 & 0 & 0.318 \\
\hline Capex & 751 & -0.06 & -0.04 & 7317 & -0.06 & -0.04 & 0 & 0.7847 \\
\hline Panel B: IC eff & & & & & & & & \\
\hline VAIC & 1578 & 3.8 & 2.62 & 1109 & 8 & 3.07 & 0 & 0 \\
\hline Firms wit & ow Bo & iender I & ersity & Firms wi & h Board & er Diversity & Differe & ce Tests \\
\hline & $\mathrm{N}$ & Mean & Median & $\mathrm{N}$ & Mean & Median & T-stat & z-stat \\
\hline & & & & & & & ( $p$-value) & ( $p$-value) \\
\hline Panel A: firm & acteristi & & & & & & & \\
\hline TA & 7191 & 22.34 & 22.35 & 7682 & 22.53 & 22.46 & 0 & 0 \\
\hline Age & 3886 & 3.23 & 3.25 & 5828 & 3.42 & 3.39 & 0 & 0 \\
\hline Growth & 7193 & 0.16 & 0.03 & 7687 & 0.08 & 0.03 & 0.0734 & 0 \\
\hline Capital ratio & 7191 & 0.46 & 0.45 & 7682 & 0.41 & 0.41 & 0 & 0.0004 \\
\hline Capex & 7167 & -0.06 & -0.05 & 766 & -0.06 & -0.04 & 0 & 0.6391 \\
\hline Panel B: IC eff & & & & & & & & \\
\hline VAIC & 1238 & 5.06 & 3.04 & 1449 & 5.94 & 2.58 & 0.0025 & 0 \\
\hline Firn & ith a $S n$ & Board S & & & a Larg & Size & Differe & ce Tests \\
\hline & $\mathrm{N}$ & Mean & Median & $\mathrm{N}$ & Mean & Median & T-stat & z-stat \\
\hline & iv & & & & & & $(p$-value) & ( $p$-value) \\
\hline Panel A: firm & acteristi & & & & & & & \\
\hline TA & 6932 & 21.8 & 21.83 & 7,941 & 23 & 22.89 & 0 & 0 \\
\hline Age & 4308 & 3.22 & 3.23 & 5,406 & 3.44 & 3.43 & 0 & 0 \\
\hline Growth & 6935 & 0.21 & 0.04 & 7,945 & 0.04 & 0.02 & 0.0001 & 0 \\
\hline Capital ratio & 6932 & 0.48 & 0.48 & 7,941 & 0.4 & 0.39 & 0 & 0 \\
\hline Capex & 6895 & -0.06 & -0.04 & 7,932 & -0.06 & -0.04 & 0 & 0.7088 \\
\hline Panel B: IC eff & & & & & & & & \\
\hline VAIC & 1214 & 5.12 & 2.69 & 1,473 & 5.88 & 2.83 & 0.0087 & 0 \\
\hline Firms & lout CE & ompens & & Firr & CEO C & sation & Differe & ce Tests \\
\hline & $\mathrm{N}$ & Mean & Median & $\mathrm{N}$ & Mean & Median & T-stat & z-stat \\
\hline & & & & & & & ( $p$-value) & ( $p$-value) \\
\hline Panel A: firm & cteristi & & & & & & & \\
\hline TA & 9722 & 22.4 & 22.38 & 5151 & 22.5 & 22.45 & 0.0001 & 0 \\
\hline Age & 5166 & 3.28 & 3.3 & 4548 & 3.42 & 3.36 & 0 & 0 \\
\hline Growth & 9726 & 0.13 & 0.03 & 5154 & 0.11 & 0.03 & 0.6653 & 0.2492 \\
\hline Capital ratio & 9722 & 0.45 & 0.44 & 5151 & 0.41 & 0.41 & 0 & 0.0272 \\
\hline Capex & 9687 & -0.06 & -0.04 & 514 & -0.06 & -0.04 & 0 & 0.8172 \\
\hline Panel B: IC eff & & & & & & & & \\
\hline VAIC & 1838 & 4.26 & 2.67 & 849 & 8.29 & 3.17 & 0 & 0 \\
\hline Firn & thout $C$ & Separat & & & th CEO & tion & Differe & ce Tests \\
\hline & $\mathrm{N}$ & Мean & Median & $N$ & Mean & Median & T-stat & z-stat \\
\hline & $N$ & Miean & Miedran & $\mathrm{N}$ & Mlean & Miedian & ( $p$-value) & $(p$-value) \\
\hline Panel A: firm & cteristi & & & & & & & \\
\hline $\mathrm{TA}$ & 8869 & 22.29 & 22.27 & 6004 & 22.67 & 22.59 & 0 & 0 \\
\hline Age & 5527 & 3.28 & 3.26 & 4187 & 3.43 & 3.41 & 0 & 0 \\
\hline Growth & 8871 & 0.15 & 0.02 & 6009 & 0.09 & 0.04 & 0.1881 & 0.0005 \\
\hline Capital ratio & 8869 & 0.44 & 0.43 & 6004 & 0.42 & 0.42 & 0 & 0.2197 \\
\hline Capex & 8829 & -0.06 & -0.05 & 5998 & -0.06 & -0.04 & 0.0062 & 0.8782 \\
\hline Panel B: IC eff & & & & & & & & \\
\hline VAIC & 1725 & 4.67 & 2.78 & 962 & 7.08 & 2.72 & 0 & 0 \\
\hline
\end{tabular}




\subsection{Empirical Strategy and Endogeneity Issues}

Our empirical strategy is to test whether firms with a high CSR engagement and better governance characteristics are more likely to have a high level of firm VAIC. However, it may be that our analysis suffers from reverse causality and simultaneity biases. Indeed, although it may be true that high levels of VAIC are the result of high levels of CSR, it may also be possible that firms with higher levels of IC efficiency have more possibilities to invest in CSR initiatives due to slack resources and good management. Accordingly, Barrena-Martinez et al. [15] indicated that firms with a high IC intensity were able to foster a greater socially responsible orientation in the management of their human resources. Furthermore, CSR engagement may be determined by various firm-level factors such as CG mechanisms, which also influence firms' IC efficiencies. To alleviate these endogeneity concerns, we perform a 2SLS regression by using an IV for our IC efficiency measure. Heckman and Robb [141] suggested using the IV approach, which is based on the search for a variable (or more than one) that influences the endogenous variable (in our case, a firm's decision to be involved in CSR activities); however, that does not directly affect the dependent variable (in our case, the VAIC) except through the endogenous variable. Thus, in the spirit of Jo and Harjoto [36], we use Age as the IV because it is positively correlated with our CSR indicators but uncorrelated with firm VAIC (see Table 2). The use of firm age as the IV can be justified by the fact that older firms can have enough money to finance CSR initiatives but do not always exhibit a higher IC efficiency. 
Table 2. The correlation matrix.

\begin{tabular}{|c|c|c|c|c|c|c|c|c|c|c|c|c|c|}
\hline & (1) & (2) & (3) & (4) & (5) & (6) & (7) & (8) & (9) & (10) & (11) & (12) & (13) \\
\hline & TA & Age & Capex & Growth & Capital ratio & CSR_1 & CSR_2 & B_ind & B_GD & B_size & CEO_comp & CEO_power & VAIC \\
\hline TA & 1.0000 & & & & & & & & & & & & \\
\hline Age & $0.1667^{* * *}$ & 1.0000 & & & & & & & & & & & \\
\hline Capex & $0.0626^{* * *}$ & $0.0965^{* * *}$ & 1.0000 & & & & & & & & & & \\
\hline Growth & $-0.0399^{* * *}$ & $-0.0292^{* * *}$ & $-0.0621^{* * *}$ & 1.0000 & & & & & & & & & \\
\hline Capital ratio & $-0.2506^{* * *}$ & $-0.0940^{* * *}$ & $-0.0650 * * *$ & $0.0260^{* * *}$ & 1.0000 & & & & & & & & \\
\hline CSR_1 & $0.4669 * * *$ & $0.2497^{* * *}$ & $0.0291^{* * *}$ & $-0.0332 * * *$ & $-0.1336^{* * *}$ & 1.0000 & & & & & & & \\
\hline CSR_2 & $0.4713^{* * *}$ & $0.2719^{* * *}$ & $0.0724^{* * *}$ & $-0.0472^{* * *}$ & $-0.1685^{* * *}$ & $0.8399^{* * *}$ & 1.0000 & & & & & & \\
\hline B_ind & -0.0045 & -0.0123 & $-0.0542 * * *$ & 0.0108 & $-0.0548^{* * *}$ & $0.1954^{* * *}$ & $0.0186^{* *}$ & 1.0000 & & & & & \\
\hline B_GD & $0.1185^{* * *}$ & $0.1208^{* * *}$ & $0.0746^{* * *}$ & $-0.0166^{* *}$ & $-0.1463^{* * *}$ & $0.2888^{* * *}$ & $0.2202^{* * *}$ & $0.3210^{* * *}$ & 1.0000 & & & & \\
\hline B_size & $0.5026^{* * *}$ & $0.1570^{* * *}$ & $0.0710^{* * *}$ & $-0.0495^{* * *}$ & $-0.1936^{* * *}$ & $0.2507^{* * *}$ & $0.3157^{* * * *}$ & $-0.0883^{* * *}$ & $0.1467^{* * *}$ & 1.0000 & & & \\
\hline CEO_comp & $0.0332 * * *$ & $0.0870^{* * *}$ & $-0.0339 * * *$ & -0.0035 & $-0.0761^{* * *}$ & $0.2297^{* * *}$ & $0.1014^{* * *}$ & $0.4695^{* * *}$ & $0.2737^{* * *}$ & $-0.0238^{* * *}$ & 1.0000 & & \\
\hline CEO_power & $0.1302^{* * *}$ & $0.0690^{* * *}$ & $0.0225^{* * *}$ & -0.0108 & $-0.0423^{* * *}$ & 0.0131 & 0.0122 & $0.1427^{* * *}$ & -0.0021 & $0.0917^{* * *}$ & $0.0428^{* * *}$ & 1.0000 & \\
\hline VAIC & $0.0984^{* * *}$ & 0.0286 & 0.0274 & $0.0404^{* *}$ & -0.0133 & $0.0611^{* * *}$ & 0.0091 & $0.3028^{* * *}$ & $0.0533^{* * *}$ & 0.0299 & $0.2510^{* * *}$ & $0.1550^{* * *}$ & 1.0000 \\
\hline
\end{tabular}

This table shows the Pearson pairwise correlation matrix. The asterisks denote a statistical significance at the $1 \%\left({ }^{* * *}\right), 5 \%\left({ }^{* *}\right)$, or $10 \%\left({ }^{*}\right)$ levels. 


\section{Empirical Results}

The Impact of CSR Engagement on Firms' VAIC

The results of the IV/2SLS estimation are reported in Table 3. Note that we first use (columns 1-8) for our primary measure of CSR engagement (CSR_1), i.e., the ASSET4's ESG score, and then use (columns 9-16) for our secondary measure of CSR engagement (CSR_2), which has been calculated as the average of the social and environment scores provided by ASSET4. Furthermore, columns (1), (3), (5), (7), (9), (11), (13), and (15) of Table 3 report the results of the first-stage regression, in which the instrument (i.e., firm age) has been used to predict the endogenous variable (i.e., CSR engagement) while controlling for other determining factors. Columns (2), (4), (6), (8), (10), (12), (14), and (16) report the results of the IV regression where the predicted value of CSR estimated through the first stage is then used as a regressor in the second-stage default regression.

Note that we begin with a baseline model in which the dependent variables are regressed on firm growth, size, leverage, and capital expenditures and on a set of industry and time dummies. Next, we first add to the baseline model various variables measuring board characteristics (i.e., B_size, B_ind, and B_GD), then the variables related to the CEO characteristics (i.e., CEO_com and CEO_power), and finally all the CG variables.

Overall, the results of the first-stage regressions show that the level of CSR engagement is positively influenced (almost always at the $1 \%$ confidence level or less) by the size of the board (B_size), the incidence of female directors out of the total number of board members (B_GD), the application of CEO compensation systems linked to shareholder return (CEO_comp), and firm size (TA) and negatively influenced (at the 1\% confidence level or less) by the firm's sales growth (Growth) and the power of the CEO within the board of directors (CEO_power). The coefficients of the variables capturing the independence of a firm's board (B_Ind) and its capital structure (Capital ratio) and capital expenditures (Capex) are not always significant. Interestingly and consistent with our argumentation that the age of a firm can be considered an acceptable instrument and that a firm's CSR engagement rises as the variable Age increases (at the $1 \%$ level or better). Since, for each endogenous variable (namely, CSR_1 and CSR_2), we have multiple first stages, we perform the Cragg-Donald f-test statistic to control for a weak identification (i.e., weak instruments) that can cause instrumental variable estimators to be biased. This test is used to indicate the relevance of the IV in the first stage. All of the f-statistics are greater than the critical value of 16.38, reported by Stock and Yogo [142], with $p$-values smaller than 0.01 in all instances. The high and positive f-statistics confirm that our IV (Age) is strongly correlated with CSR_1 and CSR_2, thus supporting the relevance of this IV.

Regarding the results of the second-stage regressions that enable us to test our research hypotheses, we find several significant factors contributing to the IC efficiency of the sample firms. Specifically, VAIC is positively influenced by a firm's sales growth (Growth) (at the $1 \%$ confidence level or better) and the level of its capital investment (Capex) (at the 10\% confidence level or better). As expected, the set of dummy variables describing industry characteristics and time periods significantly contributes to explaining a firm's IC efficiency. In contrast, the coefficients of the variables Capital ratio and TA are not significant. 
Table 3. Value-added intellectual capital (VAIC) regressions based on the IV/2SLS approach

\begin{tabular}{|c|c|c|c|c|c|c|c|c|}
\hline & -1 & -2 & -3 & -4 & -5 & -6 & -7 & -8 \\
\hline & First-Stage & Second-Stage & First-Stage & Second-Stage & First-Stage & Second-Stage & First-Stage & Second-Stage \\
\hline & CSR_1 & VAIC & CSR_1 & VAIC & CSR_1 & VAIC & CSR_1 & VAIC \\
\hline \multirow{2}{*}{ CSR_1 } & & 0.122 * & & $0.145 *$ & & $0.156^{* *}$ & & $0.188^{* *}$ \\
\hline & & -1.71 & & -1.78 & & -2.14 & & -2.13 \\
\hline \multirow{2}{*}{ B_ind } & & & $0.098 * * *$ & $0.097 * * *$ & & & $0.078 * * *$ & $0.069^{* * *}$ \\
\hline & & & -6.46 & -8.31 & & & -4.74 & -5.84 \\
\hline \multirow{2}{*}{ B_GD } & & & $0.382 * * *$ & -0.095 ** & & & $0.356^{* * *}$ & $-0.112 * * *$ \\
\hline & & & -10.5 & $(-2.43)$ & & & -9.89 & $(-2.85)$ \\
\hline \multirow{2}{*}{ B_size } & & & 2.085 & $1.491 *$ & & & $3.959 * * *$ & 0.628 \\
\hline & & & -1.36 & -1.64 & & & -2.6 & -0.63 \\
\hline \multirow{2}{*}{ CEO_comp } & & & & & $7.001^{* * *}$ & $2.519^{* * *}$ & $4.459 * * *$ & $1.246^{* *}$ \\
\hline & & & & & -9.43 & -3.8 & -5.59 & -2.03 \\
\hline \multirow{2}{*}{ CEO_power } & & & & & $-3.178^{* * *}$ & $3.763^{* * *}$ & $-4.066^{* * * *}$ & $3.279 * * *$ \\
\hline & & & & & $(-4.20)$ & -7.58 & $(-5.46)$ & -5.6 \\
\hline \multirow{2}{*}{ Growth } & $-4.044 * * *$ & 1.840 ** & $-3.971 * * *$ & $1.693 * *$ & $-3.544 * * *$ & $2.014^{* *}$ & $-3.478 * * *$ & $1.869 * *$ \\
\hline & $(-2.99)$ & -2.21 & $(-3.09)$ & -2.03 & $(-2.70)$ & -2.49 & $(-2.75)$ & -2.25 \\
\hline \multirow{2}{*}{ TA } & $4.553 * * *$ & 0.01 & $3.843^{* * *}$ & -0.128 & $4.713^{* * *}$ & -0.487 & $3.998 * * *$ & -0.497 \\
\hline & -16.56 & -0.03 & -13.22 & $(-0.36)$ & -17.2 & $(-1.23)$ & -13.84 & $(-1.24)$ \\
\hline \multirow{2}{*}{ Capital ratio } & 0.908 & -0.015 & 2.731 & -0.226 & 2.146 & -0.011 & $3.684^{* *}$ & -0.509 \\
\hline & -0.48 & $(-0.01)$ & -1.53 & $(-0.22)$ & -1.18 & $(-0.01)$ & -2.1 & $(-0.47)$ \\
\hline \multirow{2}{*}{ Capex } & 2.285 & $9.498 * *$ & -1.098 & 6.867 & 5.135 & $8.405^{*}$ & -5.645 & $7.626^{*}$ \\
\hline & -0.27 & -2.02 & $(-0.14)$ & -1.5 & $(-0.63)$ & -1.82 & $(-0.72)$ & -1.66 \\
\hline Year & Yes & Yes & Yes & Yes & Yes & Yes & Yes & Yes \\
\hline Industry & Yes & Yes & Yes & Yes & Yes & Yes & Yes & Yes \\
\hline \multirow{2}{*}{ Age (IV) } & $3.268^{* * *}$ & & $2.810 * * *$ & & $3.137 * * *$ & & $2.619 * * *$ & \\
\hline & -7.84 & & -7.04 & & -7.73 & & -6.66 & \\
\hline \multirow{2}{*}{ _cons } & $-80.778 * * *$ & 4.76 & $-60.318^{* * *}$ & 0.863 & $-83.597 * * *$ & $14.280 *$ & $-69.735 * * *$ & 10.163 \\
\hline & $(-9.67)$ & -0.68 & $(-8.56)$ & -0.12 & $(-10.20)$ & -1.96 & $(-9.89)$ & -1.28 \\
\hline$N$ & 1,713 & 1,713 & 1,708 & 1,708 & 1713 & 1,713 & 1,708 & 1,708 \\
\hline$R^{2}$ & 0.29 & 0.027 & 0.364 & 0.081 & 0.331 & 0.062 & 0.387 & 0.068 \\
\hline adj. $R^{2}$ & 0.279 & 0.012 & 0.353 & 0.065 & 0.32 & 0.046 & 0.376 & 0.05 \\
\hline First-stage Cragg-Donald F-test statistics & 613.954 & $(p=0.00)$ & 495.725 & $(p=0.00)$ & 598.265 & $(p=0.00)$ & 444.184 & $(p=0.00)$ \\
\hline
\end{tabular}


Table 3. Cont

\begin{tabular}{|c|c|c|c|c|c|c|c|c|}
\hline & -9 & -10 & -11 & -12 & -13 & -14 & -15 & -16 \\
\hline & First-Stage & Second-Stage & First-Stage & Second-Stage & First-Stage & Second-Stage & First-Stage & Second-Stage \\
\hline & CSR_2 & VAIC & CSR_2 & VAIC & CSR_2 & VAIC & CSR_2 & VAIC \\
\hline \multirow{2}{*}{ CSR_2 } & & $0.0680 *$ & & $0.081 *$ & & $0.086 * *$ & & $0.101^{* *}$ \\
\hline & & -1.7 & & -1.79 & & -2.14 & & -2.15 \\
\hline \multirow{2}{*}{ B_ind } & & & -0.004 & 0.111 *** & & & \begin{tabular}{l|l|}
-0.028 \\
\end{tabular} & $0.087^{* * *}$ \\
\hline & & & $(-0.17)$ & -12.98 & & & $(-1.04)$ & -8.99 \\
\hline \multirow{2}{*}{ B_GD } & & & $0.483^{* * *}$ & $-0.078^{* *}$ & & & $0.454^{* * *}$ & $-0.091 * * *$ \\
\hline & & & -8.34 & $(-2.50)$ & & & -7.86 & $(-2.93)$ \\
\hline \multirow{2}{*}{ B_size } & & & $8.041^{* * *}$ & 1.143 & & & $9.94 * * *$ & 0.362 \\
\hline & & & -3.31 & -1.17 & & & -4.07 & -0.35 \\
\hline \multirow{2}{*}{ CEO_comp } & & & & & $5.102 * * *$ & $3.173^{* * *}$ & $4.907 * * *$ & $1.585 * * *$ \\
\hline & & & & & -4.34 & -6.8 & -3.83 & -3.05 \\
\hline \multirow{2}{*}{ CEO_power } & & & & & $-3.678^{* * *}$ & $3.582 * * *$ & $-3.935 * * *$ & $2.915^{* * *}$ \\
\hline & & & & & $(-3.08)$ & -7.81 & $(-3.29)$ & -6.03 \\
\hline \multirow[t]{2}{*}{ Growth } & $-9.943 * * *$ & 2.025 ** & $-9.351 * * *$ & $1.874^{* *}$ & $-9.539 * * *$ & $2.279 * * *$ & $\begin{array}{c}-8.825 * * * \\
(-4.34)\end{array}$ & 2.112 ** \\
\hline & $(-4.76)$ & -2.27 & $(-4.57)$ & -2.13 & $(-4.60)$ & -2.63 & & -2.4 \\
\hline \multirow{2}{*}{ TA } & $5.725 * * *$ & 0.175 & $4.448 * * *$ & 0.069 & $5.952 * * *$ & -0.262 & $4.588^{* * *}$ & -0.212 \\
\hline & -13.46 & -0.6 & -9.62 & -0.26 & -13.73 & $(-0.87)$ & -9.88 & $(-0.76)$ \\
\hline \multirow{2}{*}{ Capital Ratio } & $-7.796^{* * * *}$ & 0.625 & $-5.273 *$ & 0.596 & $-6.780 * *$ & 0.905 & -4.276 & 0.616 \\
\hline & $(-2.69)$ & -0.57 & $(-1.86)$ & -0.58 & $(-2.35)$ & -0.86 & $(-1.52)$ & -0.6 \\
\hline \multirow{2}{*}{ Capex } & $-48.455^{* * *}$ & $13.069 * * *$ & $-47.153^{* * *}$ & 10.521 ** & $-54.322 * * *$ & 12.262 ** & $-51.914^{* * *}$ & 11.834 ** \\
\hline & $(-3.72)$ & -2.65 & $(-3.71)$ & -2.17 & $(-4.18)$ & -2.48 & $(-4.11)$ & -2.37 \\
\hline Year & Yes & Yes & Yes & Yes & Yes & Yes & Yes & Yes \\
\hline Industry & Yes & Yes & Yes & Yes & Yes & Yes & Yes & Yes \\
\hline \multirow{2}{*}{ Age (IV) } & $5.845^{* * * *}$ & & $5.034 * * *$ & & $5.705 * * *$ & & $4.845^{* * *}$ & \\
\hline & -9.06 & & -7.93 & & -8.89 & & -7.67 & \\
\hline \multirow{2}{*}{ _cons } & $-124.054 * * *$ & 3.373 & $-75.963 * * *$ & -0.435 & $-128.262 * * *$ & $12.243 *$ & $-85.377^{* * *}$ & 7.545 \\
\hline & $(-9.60)$ & -0.52 & $(-6.78)$ & $(-0.07)$ & $(-9.89)$ & -1.86 & $(-7.53)$ & -1.09 \\
\hline$N$ & 1713 & 1713 & 1708 & 1708 & 1713 & 1713 & 1708 & 1708 \\
\hline$R^{2}$ & 0.304 & 0.016 & 0.341 & 0.092 & 0.315 & 0.063 & 0.351 & 0.088 \\
\hline adj. $R^{2}$ & 0.293 & 0.0008 & 0.33 & 0.076 & 0.304 & 0.047 & 0.339 & 0.071 \\
\hline First-stage Cragg-Donald F-test statistics & 81.9935 & $(p=0.00)$ & 62.9452 & $(p=0.00)$ & 79.0329 & $(p=0.00)$ & 58.8439 & \\
\hline
\end{tabular}

This table presents the results from the 2SLS estimations using the instrumental variable (IV) method. Our IV is Age, as it is highly correlated with CSR_1 and CSR_2 but uncorrelated with VAIC. The dependent variable in the second stage (columns (2), (4), (6), (8), (10), (12), (14), and (16) is VAIC. The first-stage estimates are reported in columns (1), (3), (5), (7), (9), (11), (13), and (15). The T-statistics are reported in brackets. The asterisks denote a statistical significance at the $1 \%\left({ }^{* * *}\right), 5 \%\left({ }^{* *}\right)$, or $10 \%\left({ }^{*}\right)$ levels. In all of the analyses, firms ${ }^{\prime}$ VAICs are winsorized at the $1 \%$ and $99 \%$ levels to minimize the effect of outliers. 
Regarding the effects of CSR activities and consistent with hypothesis H.1, we find that CSR activities positively influence (at the $1 \%$ confidence level or better) a firm's IC efficiency when we correct for endogeneity concerns and control for firm-specific and industry-specific differences between sample firms. For example, regarding the results reported in column (8), the variable CSR_1 exhibits a positive $(0.188)$ and significant coefficient $(t=2.13)$, suggesting that an increase in CSR activities determines an increase in VAIC. Note that we find a very similar result when we replace CSR_1 with CSR_2 (e.g., model 16). Overall, these findings are in line with Su [28], who found that an ethical approach to business was associated with a higher level of IC subcomponents, and with Barrena-Martinez et al. [15], who argued that firms implementing socially responsible human resources policies experienced a greater increase in IC levels than other firms. Additionally, evidences from this study confirm the investigation of Lin et al. [48] on the positive relationship between CSR and IC, by expanding knowledge of a positive interaction of CSR with each IC subdimensions.

Evidences obtained from the current analysis are in line with a previous investigation [35] on the ability of CSR to encourage IC development, which in turn contribute to secure financial performance of firms. Otherwise, the results of the current paper are not consistent with Aras et al. [29], who did not find any significant relationship between CSR engagement and the efficient use of IC by firms.

Concerning the impact of CG on IC efficiency and in line with hypothesis H.2, we find that various CG characteristics significantly affect a firm's VAIC. Specifically, the variables that capture the power of a firm's CEO (CEO_power), the percentage of independent directors (B_Ind), and the connection of CEO compensation to shareholder return (CEO_comp) positively influence (at the $5 \%$ confidence level or better) VAIC. However, while the number of board directors (B_size) may not influence IC efficiency, the incidence of female directors (B_GD) in the total number of board members is negatively correlated with IC efficiency. This might be explained by the observation of Birindelli et al. [130], who asserted that the relationship between social performance and the number of women on the board followed an inverted U-shaped relationship that determined the negative relationship when the critical mass of women in the board was reached.

Overall, these findings suggest that firms may strategically choose CG practices to achieve higher levels of IC efficiency, which in turn should lead to better CFP, as demonstrated by previous studies (e.g., Reference [135]). As a whole, the results of the current paper are consistent with Keenan and Aggestam [50] and Appuhami and Bhuyan's [31] argument that the efficient use of IC depends on the CG mechanisms of firms and with the results provided by Wang [30] that CG affects the positive relationship between IC and firm market valuation.

\section{Discussion and Concluding Remarks}

The present study aimed to analyze how CSR engagement positively affects IC. Moreover, to provide a greater clarity on the causal link between CSR and IC, by assuming CSR as a multidimensional construct that includes CG mechanisms, this paper also addressed the issue of how CG is positively associated with the development of IC.

In doing so, this study sought to fill several gaps in the literature. First, we empirically held together CSR and CG while examining their relationship with IC. Second, we adopted a large multi-industry and international sample, thus increasing the generalizability of our analysis relative to prior studies [15,26-28,30,32,33]. Third, by answering to the calls of Su [28] and Altuner et al. [29], we ran a longitudinal study to collect data for a causality examination through multivariate models. Fourth, to address reverse causality concerns, in contrast with previous investigations [15], we adopted the IV/2SLS approach. Lastly, consistent with Dumay's [24,25] call, we deepened the link between CSR and IC from a management perspective rather than a reporting one.

Therefore, the findings of this study are robust and provide empirical evidence supporting the research hypotheses. In particular, we demonstrated that CSR was able to encourage IC development. Further, effective CG practices significantly increase a company's overall IC efficiency. 
The aforementioned results have several implications. At the theoretical level, this study complements the previous research in the field of both CSR and CG effects at the firm level and extends the literature on the drivers of IC in businesses. In particular, CSR is confirmed as a cospecialized asset [39] that contributes to increasing the economic value of another strategic asset such as IC. The latter is linked to trust between people, to the reputation of the organization, and to the development of a corporate identity and organizational culture. Among its expected benefits, CSR should support the definition of an organizational environment that is conducive to the creation of a network of trust relationships both internal and external to the business, facilitating the sharing and creation of different forms of knowledge that are contained within the IC. The internal dimension of CSR involves the individuals who work for a company, their motivation, and their conviction in belonging to an organization with which they can identify based on a system of shared beliefs and values. The conception of CSR as a "process of accumulating knowledge and experience" [80] (p. 1298) conceptually binds with a multidimensional construct of IC that involves the knowledge of the individuals engaged in a firm and organizational knowledge.

Further, the positive impact of CG mechanisms on IC development supports the theoretical conception of CG as a pillar of CSR [36,37]. In fact, this link is consistent with a broad view of CG that shares with IC the same emphasis on an enlarged value creation for the benefit of stakeholders [15]. Our results do not coincide with the concept of CSR as an agency problem to be mitigated through effective CG [7]. On the contrary, to the extent that, in the era of the knowledge-economy, the success of companies is a growing function of the development of IC, the positive relationship between this critical resource and CSR engagement enables a win-win model that upholds the interests of both shareholders and stakeholders. From this perspective, CG can be adequately conceived as a dimension of CSR that supports the theoretical conflict-resolution thesis $[129,143]$.

On a practical level, the results of this study have interesting implications, drawing the attention of managers and policy makers to the double-positive link between CSR commitment and CG mechanisms with the development of IC. Among practitioners, there is a growing interest in CSR and in more transparent practices of CG, especially following the dramatic effects of the financial scandals at the beginning of the twenty-first century and the financial crises triggered by the subprime bubble explosion in 2008. Our results confirm that CSR can create trustworthy relations that stimulate the sharing of tacit knowledge and its socialization into explicit and codified knowledge for the benefit of organizations. The positive link with IC is an additional reason that managers may adopt to justify their commitment to CSR. The latter is a mode that increases not only the reputation of managers but also the image and reliability of the firm. CSR becomes a tool that managers can use to select and retain the most talented people and to establish more stable relationships with stakeholders outside the company. Especially in an era of financial constraints and turbulence, the demonstration of a positive link between CSR and a critical resource such as IC may provide further economic incentives to steer businesses toward socially responsible models. Additionally, CG as a CSR dimension plays an important role in developing trustworthy behaviors and relationships with stakeholders that are the basis for generating further CI. From this perspective, it is possible to broaden the boundaries and objectives of effective CG. Indeed, socially responsible CG fosters organizational transparency, a clear identification of the responsibilities inside the firm, and the monitoring of the development of IC on individual and organizational levels.

\section{Limitations and Further Research Agenda}

Although they provide important contributions at the theoretical and practical levels, the findings of the current study also reveal some limitations. First, by referring to a holistic perspective, we adopt a synthetic measure of IC efficiency and its contribution to financial performance. Second, while we separate the CG pillar from CSR, we keep together the pillars of environmental responsibility and relationships with society. Third, the CG mechanisms under analysis refer only to the characteristics of the board of directors. 
Therefore, in light of the aforementioned limitations, a new research agenda could expand the current study in several ways such as by adopting alternative measures of IC efficiency, exploring additional CG characteristics, and disentangling the other pillars of CSR related to the environment and society as potential specific drivers of IC development.

Author Contributions: F.G. is the author of Sections 2, 2.2, 2.3 and 5; D.S. is the author of Sections 3 and 4; A.M. is the author of Section 1 together with F.G.; L.M.D. is the author of Sections 2.1 and 6.

Funding: This research received no external funding.

Conflicts of Interest: The authors declare no conflict of interest.

\section{References}

1. Verdantix. Verdantix Says Heads of Sustainability Will Spend Less on Consulting Engagements over the Next 5 Years. 2016. Available online: http://www.verdantix.com/newsroom/press-releases/verdantixsays-heads-of-sustainability-will-spend-less-on-consulting-engagements-over-the-next-5-years (accessed on 9 July 2018).

2. KPMG Survey of Corporate Responsibility Reporting. 2017. Available online: https://assets.kpmg.com/ content/dam/kpmg/xx/pdf/2017/10/kpmg-survey-of-corporate-responsibility-reporting-2017.pdf (accessed on 9 July 2018).

3. Eurosif. European SRI Study 2016. Available online: http://www.eurosif.org/wp-content/uploads/2017/ 11/SRI-study-2016-LR-.pdf (accessed on 9 July 2018).

4. Lins, K.V.; Servaes, H.; Tamayo, A. Social capital, trust, and firm performance: The value of corporate social responsibility during the financial crisis. J. Financ. 2017, 72, 1785-1824. [CrossRef]

5. Mittal, R.K.; Sinha, N.; Singh, A. An analysis of linkage between economic value added and corporate social responsibility. Manag. Decis. 2008, 46, 1437-1443. [CrossRef]

6. Cheng, B.; Ioannou, I.; Serafeim, G. Corporate social responsibility and access to finance. Strateg. Manag. J. 2014, 35, 1-23. [CrossRef]

7. Barnea, A.; Rubin, A. Corporate social responsibility as a conflict between shareholders. J. Bus. Ethics 2010, 97, 71-86. [CrossRef]

8. Esteban Sanchez, P.; Benito-Hernandez, S. CSR policies: Effects on labour productivity in Spanish micro and small manufacturing companies. J. Bus. Ethics 2015, 18, 705-724. [CrossRef]

9. Margolis, J.D.; Walsh, J.P. Misery loves companies: Rethinking social initiatives by business. Admin. Sci. Q. 2003, 48, 268-305. [CrossRef]

10. Harjoto, M.A.; Jo, H. Corporate Governance and CSR Nexus. J. Bus. Ethics 2011, 100, 45-67. [CrossRef]

11. Goyal, P.; Rahman, Z.; Kazmi, A.A. Corporate sustainability performance and firm performance research: Literature review and future research agenda. Manag. Decis. 2013, 51, 361-379. [CrossRef]

12. Stewart, T.A. Intellectual Capital: The New Wealth of Organizations; Doubleday/Currency: New York, NY, USA, 1997.

13. Edvinsson, L.; Malone, M.S. Intellectual Capital: The Proven Way to Establish Your Company's Real Value by Finding Its Hidden Brainpower; Piatkus: London, UK, 1997.

14. Youndt, M.A.; Snell, S.A. Human resource configurations, intellectual capital, and organizational performance. J. Manag. Issues 2004, 16, 337-360.

15. Barrena-Martinez, J.; López-Fernández, M.; Romero-Fernandez, P. Drivers and barriers in socially responsible human resource management. Corp. Soc. Responsib. Environ. Manag. 2018, 10, 1532. [CrossRef]

16. Cuganesan, S. Reporting organisational performance in managing human resources: Intellectual capital or stakeholder perspectives? J. Hum. Resour. Costing Account. 2006, 10, 164-188. [CrossRef]

17. Guthrie, J.; Petty, R.; Ricceri, F. The voluntary reporting of intellectual capital: Comparing evidence from Hong Kong and Australia. J. Intell. Cap. 2006, 7, 254-271. [CrossRef]

18. Pedrini, M. Human capital convergences in intellectual capital and sustainability reports. J. Intell. Cap. 2007, 8, 346-366. [CrossRef]

19. Polo, F.C.; Vázquez, D.G. Social information within the intellectual capital report. J. Int. Manag. 2008, 14, 353-363. [CrossRef] 
20. Passetti, E.; Tenucci, A.; Cinquini, L.; Frey, M. Intellectual Capital Communication: Evidence from Social and Sustainability Reporting; Paper No. 16589; Munich Personal RePEc Archive (MPRA): Munich, Germany, 2009.

21. Demartini, P.; Paoloni, P. Implementing an intellectual capital framework in practice. J. Intell. Cap. 2013, 14, 69-83. [CrossRef]

22. Demartini, C.; Trucco, S. Does intellectual capital disclosure matter for audit risk? Evidence from the UK and Italy. Sustainability 2016, 8, 867. [CrossRef]

23. Santis, S.; Bianchi, M.; Incollingo, A.; Bisogno, M. Disclosure of Intellectual Capital Components in Integrated Reporting: An Empirical Analysis. Sustainability 2019, 11, 62. [CrossRef]

24. Dumay, J. Reflections on interdisciplinary accounting research: The state of the art of intellectual capital. Account. Audit. Account. J. 2014, 27, 1257-1264. [CrossRef]

25. Dumay, J. A critical reflection on the future of intellectual capital: From reporting to disclosure. J. Intell. Cap. 2016, 17, 168-184. [CrossRef]

26. Ho, C.A.; Williams, S.M. International comparative analysis of the association between board structure and the efficiency of value added by a firm from its physical capital and intellectual capital resources. Int. J. Account. 2003, 38, 465-491. [CrossRef]

27. Aras, G.; Aybars, A.; Kutlu, O. The interaction between corporate social responsibility and value added intellectual capital: Empirical evidence from Turkey. Soc. Responsib. J. 2011, 7, 622-637. [CrossRef]

28. Su, H.Y. Business ethics and the development of intellectual capital. J. Bus. Ethics 2014, 119, 87-98. [CrossRef]

29. Altuner, D.; Çelik, S.; Güleç, T.C. The linkages among intellectual capital, corporate governance and corporate social responsibility. Corp. Govern. 2015, 15, 491-507. [CrossRef]

30. Wang, M.C. Value relevance of Tobin's $Q$ and corporate governance for the Taiwanese tourism industry. J. Bus. Ethics 2015, 130, 223-230. [CrossRef]

31. Appuhami, R.; Bhuyan, M. Examining the influence of corporate governance on intellectual capital efficiency: Evidence from top service firms in Australia. Manag. Audit. J. 2015, 30, 347-372. [CrossRef]

32. Nawaz, T. Intellectual Capital, Financial Crisis and Performance of Islamic Banks: Does Shariah Governance Matter? Int. J. Bus. Soc. 2017, 18, 211-226. [CrossRef]

33. Xu, J.; Wang, B. Intellectual Capital, Financial Performance and Companies' Sustainable Growth: Evidence from the Korean Manufacturing Industry. Sustainability 2018, 10, 4651. [CrossRef]

34. Jamali, D.; Safieddine, A.M.; Rabbath, M. Corporate governance and corporate social responsibility synergies and interrelationships. Corp. Govern. 2008, 16, 443-459. [CrossRef]

35. Renneboog, L.; Ter Horst, J.; Zhang, C. The price of ethics and stakeholder governance: The performance of socially responsible mutual funds. J. Corp. Financ. 2008, 14, 302-322. [CrossRef]

36. Jo, H.; Harjoto, M.A. The causal effect of corporate governance on corporate social responsibility. J. Bus. Ethics 2012, 106, 53-72. [CrossRef]

37. McWilliams, A.; Siegel, D.S. Creating and capturing value: Strategic corporate social responsibility, resource-based theory, and sustainable competitive advantage. J. Manag. 2011, 37, 1480-1495. [CrossRef]

38. Ferrero-Ferrero, I.; Fernández-Izquierdo, M.Á.; Muñoz-Torres, M.J. Integrating sustainability into corporate governance: An empirical study on board diversity. Corp. Soc. Responsib. Environ. Manag. 2015, 22, $193-207$. [CrossRef]

39. Pulic, A. Intellectual capital-Does it create or destroy value? Measur. Bus. Excellence 2004, 8, 62-68. [CrossRef]

40. Chen, M.C.; Cheng, S.J.; Hwang, Y. An empirical investigation of the relationship between intellectual capital and firms market value and financial performance. J. Intell. Cap. 2005, 6, 159-176. [CrossRef]

41. Laing, G.; Dunn, J.; Hughes-Lucas, S. Applying the VAIC ${ }^{\mathrm{TM}}$ model to Australian hotels. J. Intell. Cap. 2010, 11, 269-283. [CrossRef]

42. Mondal, A.; Ghosh, S.K. Intellectual capital and financial performance of Indian banks. J. Intell. Cap. 2012, 13, 515-530. [CrossRef]

43. Iazzolino, G.; Laise, D. Value added intellectual coefficient (VAIC) A methodological and critical review. J. Intell. Cap. 2013, 14, 547-563. [CrossRef]

44. Margolis, J.D.; Elfenbein, H.A.; Walsh, J.P. Does It Pay to Be Good... and Does It Matter? A Meta-Analysis of the Relationship between Corporate Social and Financial Performance. 2009. Available online: http: / / ssrn.com/abstract=1866371 (accessed on 28 March 2019). 
45. Orlitzky, M.; Schmidt, F.L.; Rynes, S.L. Corporate social and financial performance: A meta-analysis. Organ. Stud. 2003, 24, 403-441. [CrossRef]

46. Wang, Q.; Dou, J.; Jia, S. A meta-analytic review of corporate social responsibility and corporate financial performance: The moderating effect of contextual factors. Bus. Soc. 2016, 55, 1083-1121. [CrossRef]

47. López-Gamero, M.D.; Zaragoza-Sáez, P.; Claver-Cortés, E.; Molina-Azorín, J.F. Sustainable development and intangibles: Building sustainable intellectual capital. Bus. Strateg. Environ. 2011, 20, 18-37. [CrossRef]

48. Lin, C.S.; Chang, R.Y.; Dang, V. An integrated model to explain how corporate social responsibility affects corporate financial performance. Sustainability 2015, 7, 8292-8311. [CrossRef]

49. Ying, Q.; Hassan, H.; Ahmad, H. The Role of a Manager's Intangible Capabilities in Resource Acquisition and Sustainable Competitive Performance. Sustainability 2019, 11, 527. [CrossRef]

50. Keenan, J.; Aggestam, M. Corporate governance and intellectual capital: Some conceptualizations. Corp. Govern. 2001, 9, 259-275. [CrossRef]

51. Youndt, M.A.; Subramaniam, M.; Snell, S.A. Intellectual capital profiles: An examination of investments and returns. J. Manag. Stud. 2004, 41, 335-362. [CrossRef]

52. Melo, T.; Garrido-Morgado, A. Corporate reputation: A combination of social responsibility and industry. Corp. Soc. Responsib. Environ. Manag. 2012, 19, 11-31. [CrossRef]

53. Bontis, N. There's a price on your head: Managing intellectual capital strategically. Bus. Q. 1996, 60, 40-78.

54. Brammer, S.; Millington, A.; Rayton, B. The contribution of corporate social responsibility to organizational commitment. Int. J. Hum. Resour. Manag. 2007, 18, 1701-1719. [CrossRef]

55. Kim, H.R.; Lee, M.; Lee, H.T.; Kim, N.M. Corporate social responsibility and employee-company identification. J. Bus. Ethics 2010, 95, 557-569. [CrossRef]

56. Hawn, O.; Ioannou, I. Mind the gap: The interplay between external and internal actions in the case of corporate social responsibility. Strateg. Manag. J. 2016, 37, 2569-2588. [CrossRef]

57. Voegtlin, C.; Greenwood, M. Corporate social responsibility and human resource management: A systematic review and conceptual analysis. Hum. Resour. Manag. Rev. 2016, 26, 181-197. [CrossRef]

58. Wieland, J. Corporate governance, values management, and standards: A European perspective. Bus. Soc. 2005, 44, 74-93. [CrossRef]

59. Kolk, A.; Pinkse, J. The integration of corporate governance in corporate social responsibility disclosures. Corp. Soc. Responsib. Environ. Manag. 2010, 17, 15-26. [CrossRef]

60. Friedman, M. A theoretical framework for monetary analysis. J. Polit. Econ. 1970, 78, 193-238. [CrossRef]

61. Jensen, M.C.; Meckling, W.H. Theory of the firm: Managerial behavior, agency costs and ownership structure. J. Financ. Econ. 1976, 3, 305-360. [CrossRef]

62. Petty, R.; Guthrie, J. Intellectual capital literature review: Measurement, reporting and management. J. Intell. Cap. 2000, 1, 155-176. [CrossRef]

63. Holste, J.S.; Fields, D. Trust and tacit knowledge sharing and use. J. Knowl. Manag. 2010, 14, 128-140. [CrossRef]

64. Nonaka, I. A dynamic theory of organizational knowledge creation. Organ. Sci. 1994, 5, 14-37. [CrossRef]

65. Nonaka, I.; Toyama, R. A firm as a dialectical being: Towards a dynamic theory of a firm. Ind. Corp. Chang. 2002, 11, 995-1009. [CrossRef]

66. Barney, J. Firm resources and sustained competitive advantage. J. Manag. 1991, 17, 99-120. [CrossRef]

67. Kang, S.C.; Snell, S.A. Intellectual capital architectures and ambidextrous learning: A framework for human resource management. J. Manag. Stud. 2009, 46, 65-92. [CrossRef]

68. Winter, S.G. Understanding dynamic capabilities. Strateg. Manag. J. 2003, 24, 991-995. [CrossRef]

69. Putnam, R. Making Democracy Work: Civic Traditions in Modern Italy; Princeton University Press: Princeton, NJ, USA, 1993.

70. Adler, P.S.; Kwon, S.W. Social capital: Prospects for a new concept. Acad. Manag. Rev. 2002, $27,17-40$. [CrossRef]

71. Bueno, E.; Paz Salmador, M.; Rodríguez, Ó. The role of social capital in today's economy: Empirical evidence and proposal of a new model of intellectual capital. J. Intell. Cap. 2004, 5, 556-574. [CrossRef]

72. Nahapiet, J.; Ghoshal, S. Social capital, intellectual capital, and the organizational advantage. Acad. Manag. Rev. 1998, 23, 242-266. [CrossRef]

73. Barney, J.B. How a firm's capabilities affect boundary decisions. Sloan Manag. Rev. 1999, 40, 137-146. 
74. De Castro, G.M.; López, J.E.N.; Sáez, P.L. Business and social reputation: Exploring the concept and main dimensions of corporate reputation. J. Bus. Ethics 2006, 63, 361-370. [CrossRef]

75. Goh, P. Intellectual capital performance of commercial banks in Malaysia. J. Intell. Cap. 2005, 6, 385-396.

76. Schiavone, F.; Meles, A.; Verdoliva, V.; Giudice, M.D. Does location in a science park really matter for firms' intellectual capital performance? J. Intell. Cap. 2014, 15, 497-515. [CrossRef]

77. Alhassan, A.L.; Asare, N. Intellectual capital and bank productivity in emerging markets: Evidence from Ghana. Manag. Decis. 2016, 54, 589-609. [CrossRef]

78. Barnett, M.L.; Salomon, R.M. Does it pay to be really good? Addressing the shape of the relationship between social and financial performance. Strateg. Manag. J. 2012, 33, 1304-1320. [CrossRef]

79. Surroca, J.; Tribó, J.A.; Waddock, S. Corporate responsibility and financial performance: The role of intangible resources. Strateg. Manag. J. 2010, 31, 463-490. [CrossRef]

80. Tang, Z.; Hull, C.E.; Rothenberg, S. How corporate social responsibility engagement strategy moderates the CSR-financial performance relationship. J. Manag. Stud. 2012, 49, 1274-1303. [CrossRef]

81. Kim, K.H.; Kim, M.; Qian, C. Effects of corporate social responsibility on corporate financial performance: A competitive-action perspective. J. Manag. 2018, 44, 1097-1118. [CrossRef]

82. Carvalho, J.M.S.; Jonker, J.; Dentchev, N. What's in a word? An exploration of the changes in meaning of corporate social responsibility over the last century with an emphasis on the last decades. In Contemporary Issues in Corporate Social Responsibility; Lexington Books: Lanham, MD, USA, 2014; pp. 1-18.

83. Nikolaou, I.E. A framework to explicate the relationship between CSER and financial performance: An intellectual capital-based approach and knowledge-based view of firm. J. Knowl. Econ. 2017. [CrossRef]

84. Chen, Y.-S. The positive effect of green intellectual capital on competitive advantages of firms. J. Bus. Ethics 2008, 77, 271-286. [CrossRef]

85. Chen, Y.-S. The driver of green innovation and green imgae-green core competence. J. Bus. Ethics 2008, 81, 531-543. [CrossRef]

86. Yang, D.; Wang, A.X.; Zhou, K.Z.; Jiang, W. Environmental strategy, institutional force, and innovation capability: A managerial cognition perspective. J. Bus. Ethics 2018. [CrossRef]

87. Ardito, L.; Dangelico, R.M. Firm environmental performance under scrutiny: The role of strategic and organizational orientations. Corp. Soc. Responsib. Environ. Manag. 2018, 25, 426-440. [CrossRef]

88. Boiral, O. Tacit knowledge and environmental management. Long Range Plan. 2002, 35, 291-317. [CrossRef]

89. Chen, J.; Zhu, Z.; Xie, H.Y. Measuring intellectual capital: A new model and empirical study. J. Intell. Cap. 2004, 5, 195-212. [CrossRef]

90. Hopkins, M. The business case for CSR: Where are we? Int. J. Bus. Perform. Manag. 2003, 5, 125-140. [CrossRef]

91. Greening, D.W.; Turban, D.B. Corporate social performance as a competitive advantage in attracting a quality workforce. Bus. Soc. 2000, 39, 254-280. [CrossRef]

92. Gully, S.M.; Phillips, J.M.; Castellano, W.G.; Han, K.; Kim, A. A mediated moderation model of recruiting socially and environmentally responsible job applicants. Pers. Psychol. 2013, 66, 935-973. [CrossRef]

93. Brekke, K.A.; Nyborg, K. Moral Hazard and Moral Motivation: Corporate Social Responsibility as Labor Market Screening. In Memorandum; No. 2004, 25; Department of Economics, University of Oslo: Oslo, Norway, 2004.

94. Branco, M.C.; Rodrigues, L.L. Corporate social responsibility and resource-based perspectives. J. Bus. Ethics 2006, 69, 111-132. [CrossRef]

95. Polanyi, M. The logic of tacit inference. Philosophy 1966, 41, 1-18. [CrossRef]

96. Nonaka, I.; Konno, N. The concept of "Ba": Building a foundation for knowledge creation. Calif. Manag. Rev. 1998, 40, 40-54. [CrossRef]

97. Asif, M.; Searcy, C.; Zutshi, A.; Fisscher, O.A.M. An integrated management systems approach to corporate social responsibility. J. Clean. Prod. 2013, 56, 7-17. [CrossRef]

98. Darroch, J. Knowledge management, innovation and firm performance. J. Knowl. Manag. 2005, 9, 101-115. [CrossRef]

99. Mårtensson, M. A critical review of knowledge management as a management tool. J. Knowl. Manag. 2000, 4, 204-216. [CrossRef]

100. Hoffman, J.J.; Hoelscher, M.L.; Sherif, K. Social capital, knowledge management and sustained superior performance. J. Knowl. Manag. 2005, 9, 93-100. [CrossRef] 
101. Gangi, F.; Mustilli, M.; Varrone, N. The impact of corporate social responsibility (CSR) knowledge on corporate financial performance: Evidence from the European banking industry. J. Knowl. Manag. 2018, 23, 110-134. [CrossRef]

102. Carayannis, E.G.; Grigoroudis, E.; Del Giudice, M.; Della Peruta, M.R.; Sindakis, S. An exploration of contemporary organizational artifacts and routines in a sustainable excellence context. J. Knowl. Manag. 2017, 21, 35-56. [CrossRef]

103. Willard, B. The New Sustainability Advantage: Seven Business Case Benefits of a Triple Bottom Line; New Society Publishers: Gabriola Island, BC, Canada, 2002.

104. Davis, J.H.; Schoorman, F.D.; Mayer, R.C.; Tan, H.H. The trusted general manager and business unit performance: Empirical evidence of a competitive advantage. Strateg. Manag. J. 2000, 21, 563-576. [CrossRef]

105. Fombrun, C.J.; Gardberg, N. Who's tops in corporate reputation? Corp. Reput. Rev. 2000, 3, 13-17. [CrossRef]

106. Deng, X.; Xu, Y. Consumers' responses to corporate social responsibility initiatives: The mediating role of consumer-company identification. J. Bus. Ethics 2017, 142, 515-526. [CrossRef]

107. Russo, A.; Perrini, F. Investigating stakeholder theory and social capital: CSR in large firms and SMEs. J. Bus. Ethics 2010, 91, 207-221. [CrossRef]

108. Gatzert, N. The impact of corporate reputation and reputation damaging events on financial performance: Empirical evidence from the literature. Eur. Manag. J. 2015, 33, 485-499. [CrossRef]

109. Aramburu, I.A.; Pescador, I.G. The effects of corporate social responsibility on customer loyalty: The mediating effect of reputation in cooperative banks versus commercial banks in the Basque country. J. Bus. Ethics 2017, 154, 701-719. [CrossRef]

110. Kim, Y. Consumer responses to the food industry's proactive and passive environmental CSR, factoring in price as CSR tradeoff. J. Bus. Ethics 2017, 140, 307-321. [CrossRef]

111. El Ghoul, S.; Guedhami, O.; Kwok, C.C.; Mishra, D.R. Does corporate social responsibility affect the cost of capital? J. Bank. Financ. 2011, 35, 2388-2406. [CrossRef]

112. Carroll, A.B. Corporate social responsibility: Evolution of a definitional construct. Bus. Soc. 1999, 38, $268-295$. [CrossRef]

113. Schwartz, M.S.; Carroll, A.B. Integrating and unifying competing and complementary frameworks: The search for a common core in the business and society field. Bus. Soc. 2008, 47, 148-186. [CrossRef]

114. Freeman, R.E. Strategic Management: A Stakeholder Approach; Pitman: Boston, MA, USA, 1984.

115. El Akremi, A.; Perrigot, R.; Piot-Lepetit, I. Examining the drivers for franchised chains performance through the lens of the dynamic capabilities approach. J. Small Bus. Manag. 2015, 53, 145-165. [CrossRef]

116. Jensen, M.C. Value maximization, stakeholder theory, and the corporate objective function. J. Appl. Corp. Financ. 2001, 14, 8-21. [CrossRef]

117. Adrian, C.S. The rise of corporate governance. In The Accountable Corporation, Vol. 1, Praeger Perspectives; Praeger: Westport, CT, USA, 2006; pp. 3-44.

118. Fama, E.F.; Jensen, M.C. Separation of ownership and control. J. Law Econ. 1983, 26, 301-325. [CrossRef]

119. Goel, A.M.; Thakor, A.V. Overconfidence, CEO selection, and corporate governance. J. Financ. 2008, 63, 2737-2784. [CrossRef]

120. Hancock, J. (Ed.) Investing in Corporate Social Responsibility: A Guide to Best Practice; Business Planning \& the UK's Leading Companies, Kogan Page: London, UK, 2005.

121. Elkington, J. Governance for sustainability. Corp. Govern. 2006, 14, 522-529. [CrossRef]

122. Aguilera, R.; Rupp, D.; Ganapathi, J. Putting the S back in corporate social responsibility: A multilevel theory of social change in organizations. Acad. Manag. Rev. 2007, 32, 836-863. [CrossRef]

123. Fassin, Y.; Van Rossem, A. Corporate governance in the debate on CSR and ethics: Sensemaking of social issues in management by authorities and CEOs. Corp. Govern. 2009, 17, 573-593. [CrossRef]

124. Berle, A.A.; Means, G.C. The Modern Corporation and Private Property; Transaction Publishers: New Brunswick, NJ, USA, 1932.

125. Tricker, R.I. Corporate Governance; Gower Publishing: Aldershot, UK, 1984.

126. Gangi, F.; Meles, A.; Monferrà, S.; Mustilli, M. Does corporate social responsibility help the survivorship of SMEs and large firms? Glob. Financ. J. 2018. [CrossRef]

127. Monks, R.; Minow, N. Corporate Governance; Blackwell Publishing: Malden, MA, USA, 2004; Volume 3.

128. Wu, M.W.; Shen, C.H. Corporate social responsibility in the banking industry: Motives and financial performance. J. Bank. Financ. 2013, 37, 3529-3547. [CrossRef] 
129. Birindelli, G.; Dell'Atti, S.; Iannuzzi, A.; Savioli, M. Composition and Activity of the Board of Directors: Impact on ESG Performance in the Banking System. Sustainability 2018, 10, 4699. [CrossRef]

130. Waldman, D.A.; Siegel, D.S.; Javidan, M. Components of CEO transformational leadership and corporate social responsibility. J. Manag. Stud. 2006, 43, 1703-1725. [CrossRef]

131. Dittmar, A.; Mahrt-Smith, J. Corporate governance and the value of cash holdings. J. Financ. Econ. 2007, 83, 599-634. [CrossRef]

132. Saifieddine, A.; Jamali, D.; Noureddine, S. Corporate governance and intellectual capital: Evidence from academic institution. Corp. Govern. 2009, 9, 146-157. [CrossRef]

133. Dzenopoljac, V.; Yaacoub, C.; Elkanj, N.; Bontis, N. Impact of intellectual capital on corporate performance: Evidence from the Arab region. J. Intell. Cap. 2017, 18, 884-903. [CrossRef]

134. Pedro, E.; Leitão, J.; Alves, H. Back to the future of intellectual capital research: A systematic literature review. Manag. Decis. 2018, 56, 2502-2583. [CrossRef]

135. Sardo, F.; Serrasqueiro, Z. A European empirical study of the relationship between firms' intellectual capital, financial performance and market value. J. Intell. Cap. 2017, 18, 771-788. [CrossRef]

136. Pathan, S. Strong boards, CEO power and bank risk-taking. J. Bank. Financ. 2009, 33, 1340-1350. [CrossRef]

137. Solakoglu, M.N.; Demir, N. The role of firm characteristics on the relationship between gender diversity and firm performance. Manag. Decis. 2016, 54, 1407-1419. [CrossRef]

138. Chance, D.M.; Kumar, R.; Todd, R. The 'repricing' of executive stock options. J. Financ. Econ. 2000, 57, 129-154. [CrossRef]

139. El Ghoul, S.; Guedhami, O.; Kim, Y. Country-level institutions, firm value, and the role of corporate social responsibility initiatives. J. Int. Bus. Stud. 2017, 48, 360-385. [CrossRef]

140. Luo, X.; Du, S. Exploring the relationship between corporate social responsibility and firm innovation. Mark. Lett. 2015, 26, 703-714. [CrossRef]

141. Heckman, J.; Robb, R., Jr. Alternative methods for evaluating the impact of interventions. In Longitudinal Analysis of Labor Market Data; Cambridge University Press: New York, NY, USA, 1985; Chapter 4.

142. Stock, J.; Yogo, M. Asymptotic Distributions of Instrumental Variables Statistics with Many Instruments; Cambridge University Press: New York, NY, USA, 2005; Chapter 6; pp. 109-120.

143. Calton, J.M.; Payne, S.L. Coping with paradox: Multistakeholder learning dialogue as a pluralist sensemaking process for addressing messy problems. Bus. Soc. 2003, 42, 7-42. [CrossRef] 